\title{
Streptococcal inhibitor of complement-mediated lysis (SIC): an anti-inflammatory virulence determinant
}

Correspondence

Per Åkesson

per.akesson@skane.se

Received 5 March 2010

Revised 2 July 2010

Accepted 9 August 2010
Per Åkesson, ${ }^{1}$ Heiko Herwald, ${ }^{1}$ Magnus Rasmussen, ${ }^{1}$ Katarina Håkansson, ${ }^{2}$ Magnus Abrahamson, ${ }^{2}$ Ahmed A. K. Hasan, ${ }^{3} \dagger$ Alvin H. Schmaier, ${ }^{4}$ Werner Müller-Esterl ${ }^{5}$ and Lars Björck ${ }^{1}$

\author{
${ }^{1}$ Department of Clinical Sciences, Division of Infection Medicine, Lund University, BMC, B14, \\ SE-22184 Lund, Sweden \\ ${ }^{2}$ Department of Laboratory Medicine, Division of Clinical Chemistry and Pharmacology, \\ Lund University, University Hospital, SE-22185 Lund, Sweden \\ ${ }^{3}$ Department of Internal Medicine, University of Michigan, Ann Arbor, MI, USA \\ ${ }^{4}$ Department of Medicine, Division of Hematology and Oncology, Case Western Reserve University, \\ Cleveland, $\mathrm{OH}, \mathrm{USA}$ \\ ${ }^{5}$ Institute for Biochemistry II, University of Frankfurt, Frankfurt, Germany
}

\begin{abstract}
Since the late 1980s, a worldwide increase of severe Streptococcus pyogenes infections has been associated with strains of the M1 serotype, strains which all secrete the streptococcal inhibitor of complement-mediated lysis (SIC). Previous work has shown that SIC blocks complement-mediated haemolysis, inhibits the activity of antibacterial peptides and has affinity for the human plasma proteins clusterin and histidine-rich glycoprotein; the latter is a member of the cystatin protein family. The present work demonstrates that SIC binds to cystatin $\mathrm{C}$, highmolecular-mass kininogen $(\mathrm{HK})$ and low-molecular-mass kininogen, which are additional members of this protein family. The binding sites in HK are located in the cystatin-like domain D3 and the endothelial cell-binding domain D5. Immobilization of HK to cellular structures plays a central role in activation of the human contact system. SIC was found to inhibit the binding of HK to endothelial cells, and to reduce contact activation as measured by prolonged blood clotting time and impaired release of bradykinin. These results suggest that SIC modifies host defence systems, which may contribute to the virulence of $S$. pyogenes strains of the M1 serotype.
\end{abstract}

\section{INTRODUCTION}

The inflammatory response to infecting bacteria is characterized by tissue oedema, increased blood flow and pain. Activation of the human contact system generates bradykinin (BK), a potent pro-inflammatory peptide inducing increased vascular permeability, fever and pain

†Present address: National Heart, Lung and Blood Institute, National Institutes of Health, Bethesda, MD, USA.

Abbreviations: ABTS, diammonium-2,2-azino-bis-(3-ethyl-2,3-dihydrobenzthiazoline)-6-sulfonate; aPTT, activated partial thromboplastin time; $\mathrm{BK}$, bradykinin; FXI, coagulation factor XI; FXII, coagulation factor XII; $H K$, high-molecular-mass kininogen; HRG, histidine-rich glycoprotein; HRP, horseradish peroxidase; HUVECs, human umbilical vein endothelial cells; LK, low-molecular-mass kininogen; PBST, PBS containing $0.25 \%$ Tween; PK, plasma prekallikrein; PT, thromboplastin time; SIC, streptococcal inhibitor of complement-mediated lysis; TCT, thrombin clotting time.
(Bhoola et al., 1992). The contact system consists of three serine proteinases, namely coagulation factors XI and XII (FXI and FXII), plasma prekallikrein (PK), and a nonenzymic co-factor, high-molecular-mass kininogen (HK) (reviewed by Colman \& Schmaier, 1997). On artificial, negatively charged surfaces, contact system activation starts with the conversion of FXII to its active form. This event is followed by activation of PK in its complex with $\mathrm{HK}$, a complex which is anchored to negatively charged surfaces via HK. Activated PK (plasma kallikrein) then cleaves HK, leading to the release of the nonapeptide BK. Activated FXII also triggers the conversion of FXI to an active enzyme, which leads to the initiation of the intrinsic pathway of coagulation. Several studies have indicated an important role for the contact system in infection. In patients suffering from severe bacterial infections, decreased levels of contact factors have been detected and low levels of these factors have been correlated with fatal 
outcome (Mason et al., 1970; Pixley et al., 1995; van Deuren et al., 2000; Wuillemin et al., 1995). It has also been shown that several important bacterial pathogens, such as Staphylococcus aureus, Escherichia coli, Salmonella and Streptococcus pyogenes, assemble components of the contact system at their surface, resulting in BK release (Ben Nasr et al., 1996; Herwald et al., 1998; Mattsson et al., 2001). In $S$. pyogenes, HK is bound to the bacteria via the surfaceattached $M$ protein and is thus exposed to a secreted streptococcal cysteine proteinase ( $\mathrm{SpeB}$ ) that cleaves $\mathrm{HK}$ and releases BK both in vitro and in vivo (Herwald et al., 1996a). Finally, activation of the contact system at bacterial surfaces was recently shown to generate antibacterial peptides, suggesting that the contact system, in addition to its pro-coagulant and pro-inflammatory properties, is a branch of innate immunity (Frick et al., 2006). Local activation of the contact system is protective against invasive bacteria, and generalized activation of the contact system gives rise to a pathological inflammatory response.

$\mathrm{HK}$ is a multifunctional $120 \mathrm{kDa}$ glycoprotein that circulates in human plasma at a concentration of $70 \mu \mathrm{g} \mathrm{ml} l^{-1}$ (Colman \& Schmaier, 1997). It is composed of a heavy chain containing four domains (D1-D4) and a light chain comprising domains D5 and D6. During contact activation, the positively charged domain D5 is responsible for binding to cellular and anionic surfaces (Colman et al., 1997; DeLa Cadena \& Colman, 1992; Hasan et al., 1995, 1998; Herwald et al., 1996b; Wachtfogel et al., 1994), whereas D6 harbours binding sites for PK and FXI (Tait \& Fujikawa, 1987). Domain D4 holds the kinin segment, which is released as BK from the intact molecule. The first three domains of HK (D1-D3) are structurally and functionally related to the cystatin domain, a domain shared by the cystatin superfamily of proteins, molecules that function as specific inhibitors of cysteine proteinases such as cathepsins and calpains. Additionally, domain D3 contains a major site for the binding of HK to endothelial cells (Herwald et al., 1995). The $70 \mathrm{kDa}$ low-molecularmass kininogen $(\mathrm{LK})$ is generated by an alternative splicing of a single gene product. LK shares with HK the cystatinlike domains D1-D3 and domain D4, but has a unique domain D5. With respect to inhibitory capacity and distribution in body fluids, HK, LK and cystatin C (a small protein forming a single cystatin domain) represent the most important members of the cystatin superfamily of proteinase inhibitors (Abrahamson et al., 1986).

Streptococcal inhibitor of complement-mediated lysis (SIC) is a secreted protein of S. pyogenes (Åkesson et al., 1996). The sic gene is highly restricted to specific M serotypes of this human pathogen, and one of these is the common M1 serotype, associated with a worldwide increase of serious S. pyogenes infections (Martin \& Single, 1993; Musser et al., 1993). A role for SIC in S. pyogenes pathogenicity and virulence is also suggested by investigations showing that sic is uniquely variable (Stockbauer et al., 1998), and that sic variants arise rapidly by natural selection on mucosal surfaces (Hoe et al., 1999).
Moreover, an isogenic mutant of the M1 serotype that does not produce SIC was impaired in its ability to colonize murine mucosal surfaces (Lukomski et al., 2000). Finally, the finding that SIC inactivates antimicrobial proteins and peptides (Binks et al., 2005; Egesten et al., 2007; FernieKing et al., 2002; Frick et al., 2003) further supports the notion that this secreted protein adds selective advantages to $S$. pyogenes isolates of the M1 serotype.

In the original report on SIC, the protein was found to interfere with complement-mediated haemolysis and to bind clusterin and histidine-rich glycoprotein (HRG), plasma proteins that interact with the membrane attack complex of complement (Åkesson et al., 1996). However, HRG, which contains two $\mathrm{NH}_{2}$-terminal cystatin-like domains (Koide \& Odani, 1987), is also a member of the cystatin superfamily, suggesting that SIC could interact with additional members of this family of proteins. Analysis of molecular interactions between SIC and cystatins, with emphasis on HK given its crucial role in the contact system, is therefore the focus of the present work. The results show that SIC is an anti-inflammatory protein that affects $S$. pyogenes pathogenicity.

\section{METHODS}

Proteins and antisera. SIC was purified from the S. pyogenes strain AP1 (M1 serotype) as described previously (Akesson et al., 1996) by precipitation of the culture medium with $30 \%$ ammonium sulphate, and ion-exchange chromatography on Mono Q (Pharmacia) followed by gel filtration on Superose 12 (Pharmacia). The protein appeared as a single band of $34 \mathrm{kDa}$ on SDS-PAGE. The streptococcal cell-wall proteins M1 protein (Åkesson et al., 1994), protein H (Åkesson et al., 1990) and protein PAB (de Château \& Björck, 1994) were purified as described previously. Human serum albumin, fibrinogen and papain were obtained from Sigma and polyclonal human IgG was from Kabi. HRG was purified as described previously (Åkesson et al., 1996). Kininogens were purified from human plasma by affinity chromatography on carboxymethyl-papain-Sepharose (CM-papain-Sepharose) and ion-exchange chromatography on Mono Q (Pharmacia) (MüllerEsterl et al., 1988). HK used for cell binding studies was purified as reported previously (Schmaier \& Colman, 1989) and biotinylated as described by Hasan et al. (1995). Purification of recombinant proteins containing domains D3 and D5 of HK was performed as described previously (Auerswald et al., 1993; Herwald et al., 2001). Recombinant human cystatin $\mathrm{C}$ was produced and isolated as described by Abrahamson et al. (1988). Cathepsin B isolated from human liver was obtained from Calbiochem. A polyclonal rabbit antiserum was raised against cystatin $\mathrm{C}$ isolated from human urine. Polyclonal antisera to SIC and HK were raised in rabbit and sheep, respectively. The polyclonal goat anti-human HRG antiserum was a kind gift from Dr William T. Morgan, University of Missouri, Kansas City, MO, USA. Peroxidase-conjugated rabbit anti-human $\kappa$ light chain IgG was from DAKO. Peroxidase-conjugated goat anti-rabbit IgG (Bio-Rad) and donkey anti-sheep IgG (ICN) were used as secondary antibodies. SIC was radiolabelled with ${ }^{125} \mathrm{I}$ by using Bolton and Hunter reagent (Amersham Corp.) and the specific activity was $3 \mu \mathrm{Ci}(\mu \mathrm{g} \text { protein })^{-1}$.

Endothelial cells. Human umbilical vein endothelial cells (HUVECs) from primary culture were purchased from Clonetics and were established as described previously (Hasan et al., 1995). Cells were passaged two to four times in medium 199 (Life Technologies) supplemented with $10 \%$ heat-inactivated fetal calf 
serum (Flow Laboratories), penicillin-streptomycin (Life Technologies) and endothelial cell growth factor (Clonetics), and were grown to confluence on fibronectin-coated 96-well microtitre plates (Nunclon; NUNC). HUVECs were always used within $24 \mathrm{~h}$ of becoming confluent.

Binding of SIC to proteins immobilized on PVDF membranes. Proteins were applied to a PVDF membrane (Immobilon) by using a Milliblot-D system (Millipore). The membrane was blocked for $1 \mathrm{~h} \mathrm{in}$ PBS containing $0.25 \%$ Tween (PBST) and $5 \%(\mathrm{w} / \mathrm{v})$ skimmed milk, incubated for $3 \mathrm{~h}$ at room temperature with ${ }^{125}$ I-labelled SIC $\left(2 \times 10^{5}\right.$ c.p.m. $\left.\mathrm{ml}^{-1}\right)$ in $5 \mathrm{ml}$ of blocking buffer, and washed four times in PBST.

ELISA. Indirect ELISA was performed by coating microtitre plates (Maxisorb; NUNC) overnight with proteins in coating buffer $(0.05 \mathrm{M}$ $\mathrm{NaHCO}_{3}, \mathrm{pH}$ 9.6) in serial dilutions $\left(2^{n}\right.$, starting concentration 2 or $10 \mu \mathrm{g} \mathrm{ml}^{-1}$ ). The plates were washed in PBST and blocked with $2 \%$ BSA (Sigma Chemical). Wells were then incubated with purified cystatin $\mathrm{C}, \mathrm{HK}$, recombinant fragments of $\mathrm{HK}$ corresponding to domain D3 or D5, LK, HRG or IgG (all at $2 \mu \mathrm{g} \mathrm{ml}^{-1}$ ). Bound proteins were detected with specific polyclonal antisera against cystatin C $(1: 40000, \mathrm{v} / \mathrm{v})$, kininogens $(1: 5000)$ or HRG $(1: 2000)$. Binding was visualized by a horseradish peroxidase (HRP)-conjugated secondary antibody against rabbit or sheep $\operatorname{IgG}(1: 5000, \mathrm{v} / \mathrm{v})$. IgG binding was detected by peroxidase-conjugated antibodies against human IgG $(1: 1000)$. All incubations were done at $37^{\circ} \mathrm{C}$ for $1 \mathrm{~h}$ and were followed by a washing step. Substrate solution $[0.1 \%(w / v)$ diammonium-2,2-azino-bis-(3-ethyl-2,3-dihydrobenzthiazoline)-6sulfonate (ABTS), $0.012 \%(\mathrm{v} / \mathrm{v}) \mathrm{H}_{2} \mathrm{O}_{2}$ in $100 \mathrm{mM}$ citric acid, $100 \mathrm{mM}$ $\left.\mathrm{NaH}_{2} \mathrm{PO}_{4}, \mathrm{pH} 4.5\right]$ was added and the change in absorbance at $405 \mathrm{~nm}$ $\left(A_{405}\right)$ was determined after $30 \mathrm{~min}$. Microtitre plates were also coated with protein SIC or protein $\mathrm{PAB}$ at $2 \mu \mathrm{g} \mathrm{ml}{ }^{-1}$, and incubated with fresh human plasma in a dilution series (starting dilution $1: 20$ ). Before testing for cystatin $\mathrm{C}$ binding, the undiluted plasma was supplemented with purified cystatin $\mathrm{C}\left(10 \mu \mathrm{g} \mathrm{ml} \mathrm{g}^{-1}\right)$. Bound cystatin $\mathrm{C}$ or kininogens were detected as described above. Competitive ELISAs were performed by using the same procedure as specified above except that microtitre plates coated with protein SIC $\left(1.25 \mu \mathrm{g} \mathrm{ml}^{-1}\right)$ were incubated with a mixture of cystatin $\mathrm{C}\left(0.05 \mu \mathrm{g} \mathrm{ml}^{-1}\right)$ and serial dilutions of the competitor proteins. Bound cystatin $\mathrm{C}$ was detected by a specific rabbit antiserum $(1: 40000, \mathrm{v} / \mathrm{v})$ followed by a secondary antibody against rabbit $\operatorname{IgG}(1: 3000, \mathrm{v} / \mathrm{v})$ and $\mathrm{ABTS} / \mathrm{H}_{2} \mathrm{O}_{2}$.

Clotting assays. Clotting time was measured in a coagulometer (Amelung). Citrate-treated human plasma $(100 \mu \mathrm{l})$ was preincubated with $30 \mu \mathrm{l}$ of a serial dilution of SIC $\left(2 \mathrm{mg} \mathrm{ml}^{-1}\right.$, dilution $\left.2^{n}\right)$ for $60 \mathrm{~min}$ at room temperature. Clotting was initiated by the addition of the preincubated plasma samples to $100 \mu \mathrm{l}$ Platelin LS [activated partial thromboplastin time (aPTT) kit; Organon Teknica] for $200 \mathrm{~s}$ at $37{ }^{\circ} \mathrm{C}$ followed by the addition of $100 \mu \mathrm{l} 25 \mathrm{mM} \mathrm{CaCl}_{2}$ (aPTT), $200 \mu \mathrm{l}$ Thromboplastin-XS with calcium (Sigma Chemical) (thromboplastin time; PT). To monitor the thrombin clotting time (TCT), $200 \mu \mathrm{l}$ of the preincubated plasma samples was treated with $200 \mu \mathrm{l}$ of the Thrombin Time Reagent (Sigma Chemical).

BK assays. Plasma $(25 \mu \mathrm{l})$ was preincubated with $25 \mu \mathrm{l}$ of a serial dilution of SIC $\left(1.25 \mathrm{mg} \mathrm{ml}^{-1}\right.$, dilution $\left.2^{n}\right)$ for $30 \mathrm{~min}$ at $37^{\circ} \mathrm{C}$. Samples were then added to $50 \mu \mathrm{l}$ aPTT reagent for $30 \mathrm{~s}$ and the amount of released BK from $2 \mu \mathrm{l}$ of the reaction mixture was determined by a competitive ELISA. Untreated plasma and plasma after activation with kaolin (aPTT reagent) in the absence of SIC were used as controls. The kinin concentrations in the reaction mixtures were quantified by using a Markit-A kit (Dainippon Pharmaceutical) as described previously (Herwald et al., 2001). Briefly, $2 \mu$ l of the plasma samples was added to $198 \mu \mathrm{l}$ of a sodium citrate buffer $(12.9 \mathrm{mM}$, $\mathrm{pH}$ 7.4) and mixed with $40 \mu \mathrm{l}$ of the deproteinizing reagent. Samples were centrifuged at $1500 \mathrm{~g}$ for $10 \mathrm{~min}$. Aliquots of the supernatant ( $60 \mu \mathrm{l}$ each) were mixed with $60 \mu \mathrm{l}$ of the kit buffer, and were applied to the wells ( $100 \mu \mathrm{l}$ each) of microtitre plates coated with capture antibodies to rabbit Ig followed by specific anti-BK Ig. After $1 \mathrm{~h}$ of incubation, the peroxidase-labelled BK probe was applied and incubated for $1 \mathrm{~h}$. The amount of bound peroxidase was visualized by the substrate solution (see ELISA above) for $30 \mathrm{~min}$. The change in absorbance was read at $405 \mathrm{~nm}$. Reference standards were prepared according to the manufacturer's instructions. Measurements were performed at least three times, in duplicate each time.

Endothelial cell binding assay. HUVECs grown to confluence on 96-well microtitre plates $\left(4 \times 10^{4}\right.$ cells per well) were washed five times in HEPES-Tyrode's buffer $(0.135 \mathrm{M} \mathrm{NaCl}, 2.7 \mathrm{mM} \mathrm{KCl}, 11.9 \mathrm{mM}$ $\mathrm{NaHCO}_{3}, 0.36 \mathrm{mM} \mathrm{NaH} \mathrm{PO}_{4}, 14.7 \mathrm{mM}$ HEPES containing $3.5 \mathrm{mg}$ BSA ml ${ }^{-1}, 3.5 \mathrm{mg}$ glucose $\left.\mathrm{ml}^{-1}, \mathrm{pH} 7.35\right)$ containing $50 \mu \mathrm{M} \mathrm{Zn}^{2+}$. Cells were incubated with $20 \mathrm{nM}$ biotinylated HK (Herwald et al., 1996b) in HEPES-Tyrode's buffer containing $50 \mu \mathrm{M} \mathrm{Zn}^{2+}$ at $37{ }^{\circ} \mathrm{C}$ for $1 \mathrm{~h}$ in the absence or presence of various competitor proteins: SIC (1$200 \mu \mathrm{M})$, cystatin $\mathrm{C}(1-100 \mu \mathrm{M})$ or $\mathrm{CM}$-papain $(1-30 \mu \mathrm{M})$. After washing the cells three times with HEPES-Tyrode's buffer containing $50 \mu \mathrm{M} \mathrm{Zn}^{2+}$ they were incubated for $1 \mathrm{~h}$ with $100 \mathrm{ml}$ of ImmunoPure streptavidin-HRP conjugate (Pierce) in a 1:500 dilution. Cells were then quickly washed five times with PBS, and the substrate, a peroxidase-specific fast reacting substrate, $3,3^{\prime}, 5,5^{\prime}$, tetramethylbenzidine dihydrochloride (turbo-TMB; Pierce), was added for $5 \mathrm{~min}$ at room temperature. The colour reaction was stopped by adding $1 \mathrm{M}$ phosphoric acid and bound biotinylated protein was quantified by measuring the absorbance of the reaction mixture at $450 \mathrm{~nm}$ by using a Microplate auto reader EL 311 (Bio-Tek Instrument). Non-specific binding was determined by measuring binding in the presence of a 50fold molar excess unlabelled $\mathrm{HK}$, and was approximately $10 \%$.

Enzyme inhibition assays. To determine the influence of SIC on the ability of cystatins to inhibit target cysteine proteinases, the interaction of cystatin $\mathrm{C}$ with cathepsin B was investigated with enzyme assays as described in detail previously (Abrahamson, 1994). Under both titrating conditions (i.e. with $[E]$ and $[I]$ at $\sim 100 \mathrm{nM}$, which is much greater than the $K_{\mathrm{i}}$ value for the cystatin C-cathepsin B complex) and in equilibrium assays using a sensitive fluorogenic substrate (with $[E]$ around $0.1 \mathrm{nM}$ and $[I] 0.1-50 \mathrm{nM})$, the effects of SIC addition (10$1000 \mu \mathrm{g} \mathrm{ml}^{-1}$ ) were tested. To investigate whether SIC binds the cystatin C-cathepsin B complex, microtitre plates were coated overnight with SIC at a concentration of $5 \mu \mathrm{g} \mathrm{ml}^{-1}$ in coating buffer (see ELISA above). Plates were washed in PBST and blocked with $2 \%$ BSA. Wells were then incubated with $0.2 \mathrm{ml}$ cathepsin B $\left(40 \mu \mathrm{g} \mathrm{ml}^{-1}\right)$ or $0.2 \mathrm{ml}$ cystatin $\mathrm{C}\left(20 \mu \mathrm{g} \mathrm{ml}^{-1}\right)$ in $0.1 \mathrm{M}$ phosphate buffer, $\mathrm{pH} 6.5$, containing $1 \mathrm{mM} \mathrm{DTT}$ and $1 \mathrm{mM}$ EDTA. In addition, cathepsin $\mathrm{B}$ was applied to wells that had already been incubated with cystatin $C$ for $60 \mathrm{~min}$ at $25{ }^{\circ} \mathrm{C}$. After incubation for $15 \mathrm{~min}$, the contents in the wells were subjected to chromogenic assay by using the substrate Bz-ArgpNA (Bachem Feinchemikalien). Absorbance was measured by using a Titertek plate reader at $405 \mathrm{~nm}$. In addition, cystatin $\mathrm{C}$ bound to the wells was measured as described above (ELISA). The content of the wells was analysed by charge-separating agarose gel electrophoresis (Abrahamson et al., 1986) to verify that the amounts of cystatin C and cathepsin B added to wells were equimolar and that a stoichiometric complex was formed in the mixture containing the two proteins.

\section{RESULTS}

\section{SIC binds cystatin $C$ and kininogens}

To investigate a possible interaction between SIC and members of the cystatin protein superfamily, immobilized 
SIC was incubated with human plasma and bound proteins were detected with specific antisera that recognize kininogens and cystatin $\mathrm{C}$, respectively. A strong signal was found with anti-kininogen antibodies indicating that kininogens are absorbed from human plasma by immobilized SIC (Fig. 1). Under the same conditions, no significant absorption of cystatin C by SIC was detected (data not shown). The plasma concentration of cystatin $\mathrm{C}$ is $0.8-2.5 \mu \mathrm{g} \mathrm{ml}$ (Grubb, 1992), which is considerably lower than that of HK $\left(70 \mu \mathrm{g} \mathrm{ml}^{-1}\right)$ or LK $\left(130 \mu \mathrm{g} \mathrm{ml}^{-1}\right)$ (Müller-Esterl et al., 1988). When the experiment was performed with plasma supplemented with purified cystatin $\mathrm{C}$ to a final concentration of $10 \mu \mathrm{g} \mathrm{ml}^{-1}$, cystatin $\mathrm{C}$ in this sample was bound to the immobilized SIC and was detected by specific antibodies (Fig. 1). The control, albumin-binding protein $\mathrm{PAB}$ of the Gram-positive bacterium Finegoldia magna (de Château \& Björck, 1994), showed no interaction with any of these plasma proteins.

As the antibodies do not discriminate between the two types of kininogens, the binding of purified HK and LK to SIC was tested in an indirect ELISA. Both forms of kininogen bound to the immobilized SIC, demonstrating that these plasma proteins are likely to bind SIC via their common sequence portions (Fig. 2a). HRG purified from human plasma was used as a positive control, whereas human IgG (used to exclude non-specific binding to SIC) failed to give a significant signal even at the highest concentration applied $\left(10 \mu \mathrm{g} \mathrm{ml}^{-1}\right)$. Purified cystatin C also bound to immobilized SIC under the same conditions

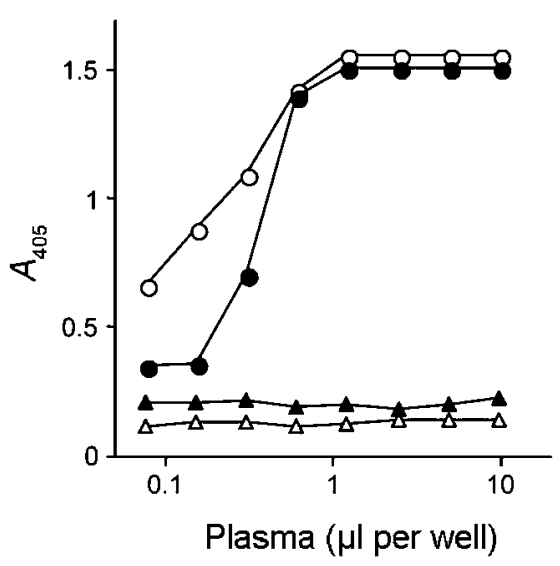

Fig. 1. Cystatin $C$ and kininogens in human plasma interact with immobilized SIC. SIC (circles) or the albumin binding protein PAB of $F$. magnus (triangles) were immobilized on microtitre plates and incubated with plasma in dilution series starting at 1:20. When binding of cystatin $\mathrm{C}$ was investigated, the plasma was supplemented with $10 \mu \mathrm{g}$ cystatin $\mathrm{C} \mathrm{ml}^{-1}$ prior to dilution. After washing, bound cystatin $\mathrm{C}$ was detected with specific cystatin $\mathrm{C}$ antibodies (closed symbols), and kininogens with antibodies recognizing both HK and LK (open symbols). Bound antibodies were visualized after incubation with peroxidase-labelled secondary antibodies. Results from one of three representative experiments are shown.
(Fig. 2b). The specificity of this binding was demonstrated by the lack of reaction between cystatin $\mathrm{C}$ and various proteins immobilized on the titre plates: albumin, $\operatorname{IgG}$ and the streptococcal proteins $\mathrm{H}$ and $\mathrm{M} 1$ (Fig. 2b). The interactions between SIC and cystatin C and HK were also demonstrated in reciprocal binding experiments in which cystatin $\mathrm{C}, \mathrm{HK}$ and albumin were immobilized on a PVDF membrane, and probed with radiolabelled SIC. SIC bound to cystatin $\mathrm{C}$ and $\mathrm{HK}$ in a dose-dependent manner, but not to albumin (Fig. 3).

\section{In HK, domains D3 and D5 bind SIC}

To determine the relationship between the binding of different members of the cystatin superfamily to SIC, a competitive ELISA was designed in which HRG and kininogens competed with cystatin $\mathrm{C}$ for SIC binding. Both HRG and kininogens inhibited the binding of cystatin C to SIC (data not shown), suggesting that a common structure among the cystatins binds to the same region of SIC. Of the three cystatin domains in HK, D3 has the highest similarity to cystatin $\mathrm{C}$, making this domain a candidate for the interaction with SIC. In addition, domain D5 of HK, which has long stretches of positively charged amino acids, is also a candidate binding site for the anionic SIC ( $\mathrm{pI}=4.2)$. In ELISA experiments, domains D3 and D5 both bound to immobilized SIC (Fig. 4), demonstrating the presence of at least two binding sites for SIC in HK.

\section{Contact phase activation is inhibited by SIC}

During activation of the contact system, the binding of HK to a negatively charged surface is essential. This step precedes the conversion of prekallikrein to its active form and the subsequent proteolysis of FXI and HK. As domain $\mathrm{D} 5$ of $\mathrm{HK}$ is essential for binding to surfaces, investigations determined whether SIC modulates contact activation in the presence of kaolin, a negatively charged particle. First, the ability of SIC to inhibit coagulation of human plasma initiated by contact activation (intrinsic pathway) was analysed. As shown in Fig. 5, SIC prolonged the intrinsic clotting time (aPTT) of normal human plasma. In contrast, SIC had no effect on the extrinsic pathway of coagulation (PT) or thrombin-induced fibrin polymerization (TCT) (data not shown). Next, the ability of SIC to interfere with the generation of BK in plasma was determined. Preincubation of plasma with SIC prior to the addition of kaolin in the aPTT test reduced BK release. This attenuation of BK formation was concentration dependent (Fig. 6). Together, these data demonstrated that the binding of SIC to $\mathrm{HK}$ inhibits contact activation on negatively charged surfaces.

\section{SIC inhibits the binding of HK to endothelial cells}

The release of BK is also facilitated by the specific binding of kininogens to the surface of their target cells such as neutrophils, platelets and endothelial cells. As HK interacts 


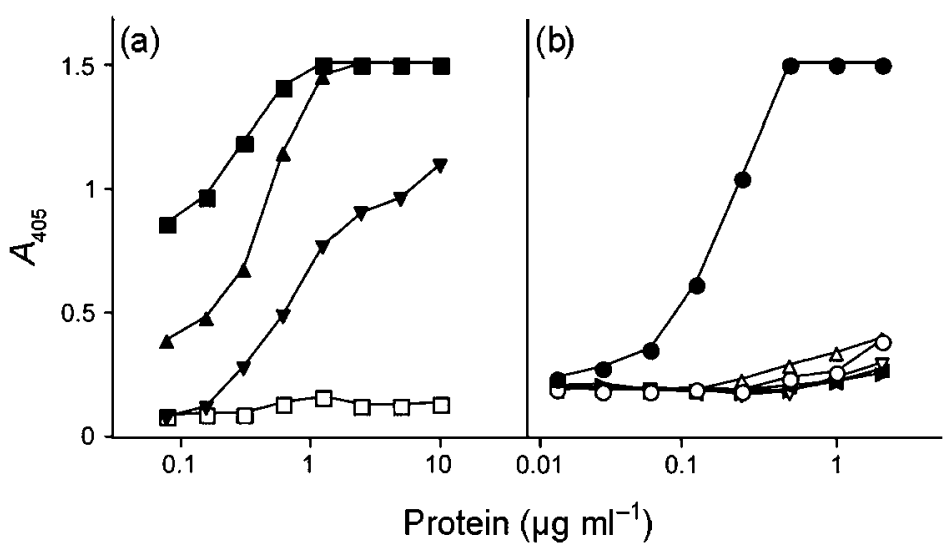

Fig. 2. Binding of HRG, kininogens and cystatin $\mathrm{C}$ to protein $\mathrm{SIC}$ in an indirect ELISA. (a) Microtitre plates were coated with dilution series of protein SIC and incubated with HRG (ם), HK ( $\boldsymbol{\Delta})$, LK ( $\boldsymbol{\nabla}$ ) or IgG ( $\square$ ) (all at $2 \mu \mathrm{g} \mathrm{m}^{-1}$ ). Binding was detected by specific antibodies to HRG and the kininogens followed by a peroxidase-labelled secondary antibody. In the case of $\operatorname{lgG}$, a peroxidase-labelled anti-lg antibody was used for detection. (b) Binding of cystatin $\mathrm{C}\left(2 \mu \mathrm{g} \mathrm{ml}^{-1}\right)$ to dilution series of coated protein $\operatorname{SIC}(\bullet), M 1$ protein $(\bullet)$, protein $H(\bigcirc)$, human serum albumin $(\nabla)$, human $\lg G$ $(\triangleleft)$ or fibrinogen $(\triangle)$ was tested. Bound cystatin $\mathrm{C}$ was detected as described in Methods. Results from one of three representative experiments are shown. with cells via sites on domains D3 and D5, we investigated whether SIC interfered with these interactions. SIC showed a dose-dependent inhibition (tested at 1-200 $\mu \mathrm{M}$ ) of the binding of biotinylated HK to endothelial cells (Fig. 7). The inhibitory effect of SIC on HK binding to endothelial cells was similar to the concentration-dependent effect of 1-30 $\mu \mathrm{M} \mathrm{CM}$-papain, whereas cystatin $\mathrm{C}$ at $1-100 \mu \mathrm{M}$ had no effect. The results suggest that SIC may displace HK bound to cell surfaces. Furthermore, although cystatin C and HK bind to the same region of SIC, they do not compete for the same binding site on endothelial cells.

\section{SIC does not influence the proteinase inhibitory function of cystatins}

As SIC binds to cystatin C and domain D3 of kininogens, it could influence the cysteine proteinase-inhibitory function of these proteins. The major human cysteine proteinase cathepsin $\mathrm{B}$ is tightly bound to and is inactivated by cystatins $\left(K_{\mathrm{i}}\right.$ values for cystatin C and LK of 0.29 and

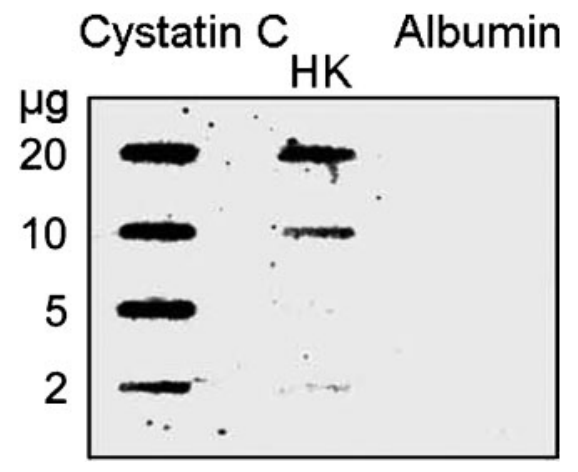

Fig. 3. Binding of radiolabelled $S I C$ to immobilized cystatin $C$ and HK. Various amounts of cystatin $\mathrm{C}, \mathrm{HK}$ and human serum albumin were applied in slots to a PVDF membrane and probed with ${ }^{125}$ I-labelled SIC $\left(2 \times 10^{5}\right.$ c.p.m. $\left.\mathrm{ml}^{-1}\right)$ for $3 \mathrm{~h}$.
$30 \mathrm{nM}$, respectively; Abrahamson et al., 1986). When SIC was added to assays monitoring the amount of free cathepsin B activity in equilibrium assays with mixtures of cathepsin B and cystatin C (enzyme and inhibitor concentrations around the $K_{\mathrm{i}}$ value), no significant effect on the ability of cystatin $C$ to inhibit cathepsin B was seen. The same was true for assays with cathepsin B and cystatin $\mathrm{C}$ at concentrations much greater than the $K_{\mathrm{i}}$ value for their interaction; SIC in solution at concentrations of 10 $1000 \mu \mathrm{g} \mathrm{ml}^{-1}$ did not affect the stoichiometric binding of cystatin $\mathrm{C}$ to cathepsin B. In agreement with this, ELISA experiments demonstrated that cathepsin B did not compete with cystatin $\mathrm{C}$ for the binding to immobilized SIC, i.e. SIC appeared not to bind a structure in cystatin C that is essential for proteinase binding/inactivation (Fig. 8).

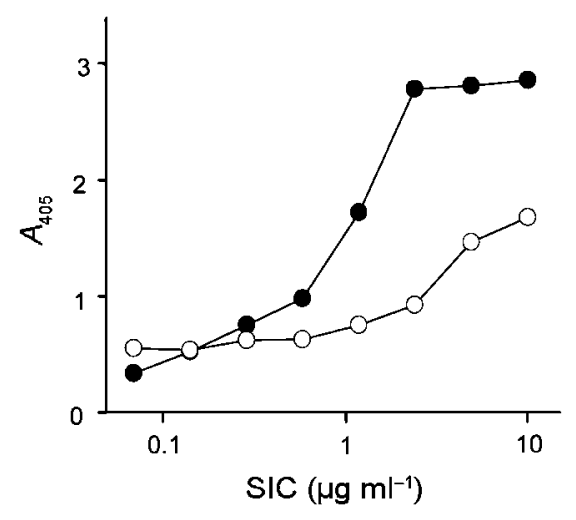

Fig. 4. SIC binds to domains D3 and D5 of HK. Microtitre plates were coated with dilution series of SIC and incubated with domain D3 (๑) or domain D5 $(\bigcirc)$ of HK (both at $2 \mu \mathrm{g} \mathrm{ml}^{-1}$ ). After washing, bound proteins were detected with a polyclonal antiserum against HK. Bound antibodies were detected with peroxidase-labelled secondary antibodies. Results from one of at least three representative experiments are shown. 


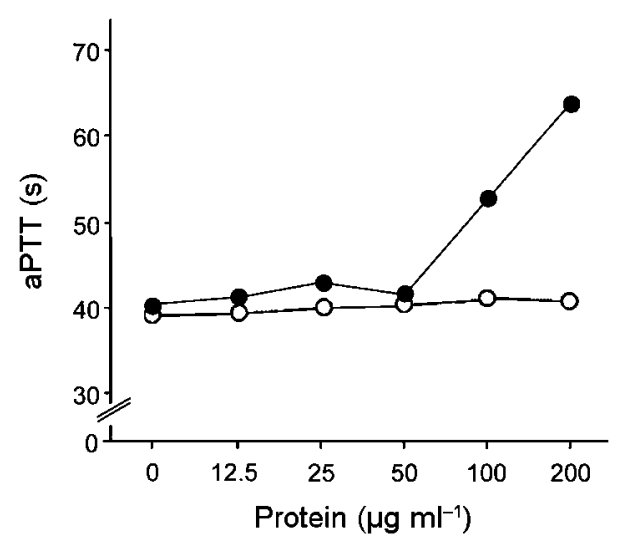

Fig. 5. SIC inhibits kaolin-induced plasma clotting. Human plasma samples were preincubated with various concentrations of SIC (๑) or protein PAB of $F$. magnus $(\bigcirc)$ for 60 min and subsequently analysed by the aPTT test.

\section{DISCUSSION}

S. pyogenes is an important human pathogen causing not only common suppurative skin and throat infections but also invasive and toxic infections with high mortality (Curtis, 1996). Strains of $S$. pyogenes can be divided into more than 120 different M serotypes (Facklam et al., 2002; Fischetti, 1989). The most frequent serotype in current

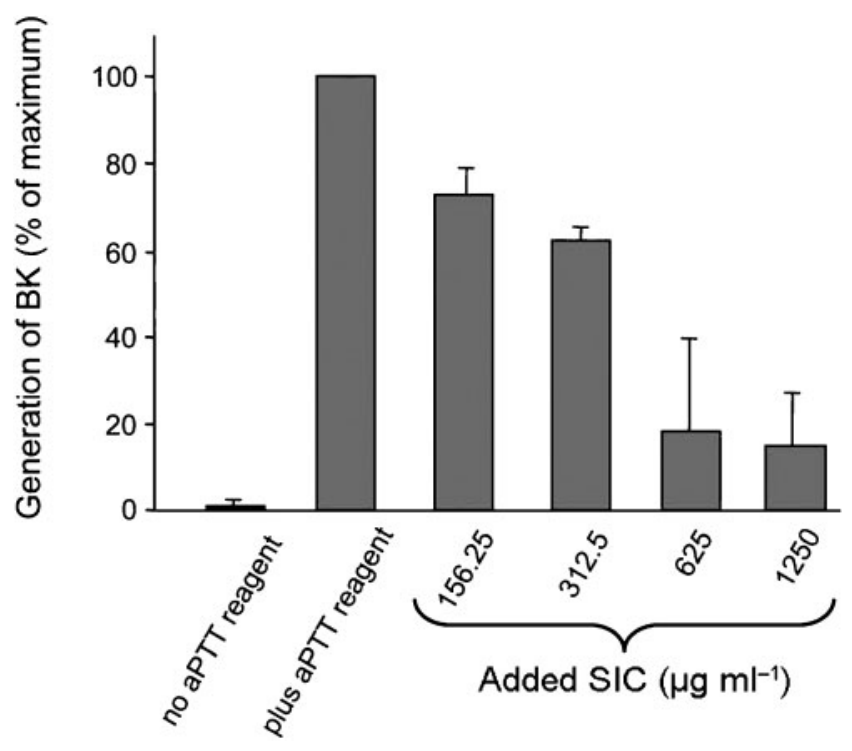

Fig. 6. SIC blocks BK generation. Twenty-five microlitres of human plasma was incubated with $25 \mu \mathrm{ISIC}$ of various concentrations for $30 \mathrm{~min}$. After the addition of the aPTT reagent kaolin $(50 \mu \mathrm{l})$, the amount of BK in $2 \mu$ of the reaction mixtures was determined by a competitive ELISA. Plasma not incubated with SIC or kaolin ('no aPTT reagent') and plasma activated by kaolin in the absence of SIC ('plus aPTT reagent') were negative and positive controls, respectively. Bars, SEM.

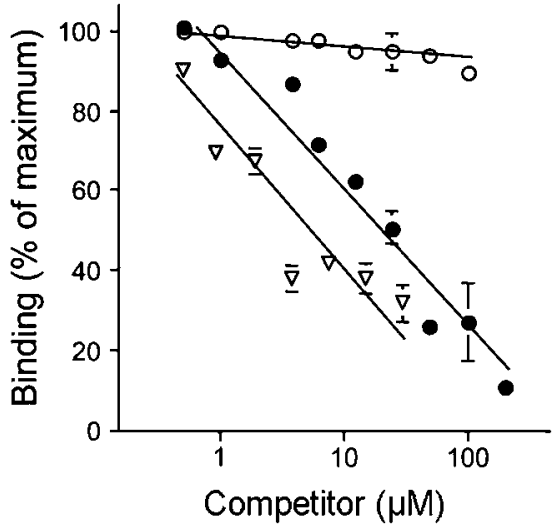

Fig. 7. SIC interferes with HK binding to endothelial cells. BiotinHK (20 nM) was added to endothelial cells (HUVEC) in HEPES-

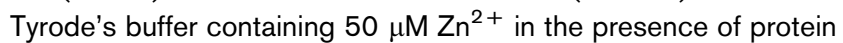
$\operatorname{SIC}(\bullet, 1-200 \mu \mathrm{M}), \mathrm{CM}-$ papain $(\nabla, 1-30 \mu \mathrm{M})$ or cystatin $\mathrm{C}(\bigcirc$, $1-100 \mu \mathrm{M})$. The proportion of biotin-HK bound to HUVECs was determined in the presence of each competitor protein after nonspecific binding was subtracted. Non-specific binding was determined by the level of binding seen in the presence of a 50fold molar excess of unlabelled HK. Data presented are the mean \pm SEM of three experiments. The absence of error bars at some data points indicates a small deviation of values.

clinical isolates is the M1 serotype, which is also the most common serotype in surveys of serious and invasive $S$. pyogenes infections worldwide (for references, see Musser \&

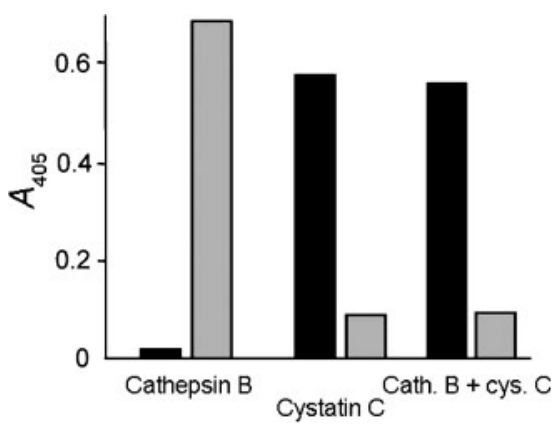

Fig. 8. Cystatin $C$ binding by $S I C$ is not affected by cathepsin B complex formation. Microtitre plates were coated with SIC and then incubated with $0.2 \mathrm{ml} \mathrm{pH} 6.5$ buffer containing cathepsin B $\left(40 \mu \mathrm{g} \mathrm{ml}^{-1}\right)$, cystatin $\mathrm{C}\left(20 \mu \mathrm{g} \mathrm{ml}^{-1}\right)$ or cathepsin $\mathrm{B}$ applied to wells that had already been incubated with cystatin $C$ for $60 \mathrm{~min}$ at $25{ }^{\circ} \mathrm{C}$. After incubation for $15 \mathrm{~min}$, the contents in the wells were subjected to chromogenic assay using the substrate Bz-Arg-pNA (grey bars), and cystatin $\mathrm{C}$ bound to the wells coated with SIC was detected by specific antibodies followed by peroxidase-labelled secondary antibodies (black bars). No cathepsin B activity over background levels was detected, verifying that virtually all cystatin $C$ is available for cathepsin B binding despite preincubation with SIC and, conversely, that cathepsin B-cystatin $\mathrm{C}$ complexes are bound by SIC. Results of one representative experiment out of four are shown. 
Krause, 1998). When S. pyogenes strains of 55 different M serotypes were analysed, only M1 and M57 strains had the sic gene and expressed SIC (Akesson et al., 1996). However, subsequent work has identified a distantly related sic gene also in M12 and M55 strains (Hartas \& Sriprakash, 1999). The sic gene is the most polymorphic gene so far identified among $S$. pyogenes isolates of the same $M$ serotype (Stockbauer et al., 1998). The functional-biological significance of this polymorphism was emphasized by the observation that virtually all nucleotide changes in sic result in amino acid substitutions, and that sic variation is associated with temporal shifts in disease frequency. The high level of sic variation probably reflects natural selection by which SIC is adapted to various host factors, and the original study on SIC suggested that inhibition of complement could represent such a factor (Åkesson et al., 1996).

The specificity of the interactions between SIC and different members of the cystatin superfamily (HRG, cystatin $\mathrm{C}, \mathrm{HK}$ and $\mathrm{LK}$ ) is emphasized by the binding between SIC and these proteins in a plasma environment. No binding between cystatin C and SIC could be detected until human plasma was supplemented by purified cystatin $\mathrm{C}$ to about ten times its normal plasma concentration, reflecting the molar excess of kininogens over cystatin $\mathrm{C}$ in plasma. However, kininogens are confined to the plasma compartment whereas cystatin $\mathrm{C}$ is present also in other extracellular fluids (Abrahamson et al., 1986). For example, in saliva, which is the in vivo environment for $S$. pyogenes during throat infections, cystatin $\mathrm{C}$ is present at a concentration similar to that in plasma $\left(1 \mu \mathrm{g} \mathrm{ml}^{-1}\right)$, whereas kininogens are not present.

SIC was shown to bind to the complex between cystatin C and one of its human target proteinases, cathepsin $\mathrm{B}$. However, the inhibitory effect of cystatin $\mathrm{C}$ on proteinase activity was not affected by SIC, indicating that SIC does not interfere with regions in cystatin $\mathrm{C}$ that are essential for its proteinase inhibitory function. As mentioned previously, SIC also binds and inactivates antibacterial proteins [secretory leukocyte peptidase inhibitor (SLPI) and lysozyme]. SLPI is an inhibitor of a wide range of serine proteinases, but analogous to the SIC-cystatin C interaction, SIC is unable to inhibit the anti-proteinase activity of SLPI (Fernie-King et al., 2002).

The interaction between SIC and HK was mapped to the D3 and D5 domains, which are responsible for the binding of $\mathrm{HK}$ to cell surfaces. Immobilization of $\mathrm{HK}$ is a prerequisite for the assembly of the contact factors and the subsequent activation of the pro-inflammatory contact system. In a recent study, a peptide derived from the cellbinding site of the D5 domain of HK was found to block the assembly and activation of the contact system in vitro (Oehmcke et al., 2009). The peptide also prevented lung bleeds and tissue damage in mice infected with $S$. pyogenes. Inhibition of the binding of $\mathrm{HK}$ to endothelial cells and inhibition of kaolin-induced contact activation by SIC suggest that SIC serves as an anti-inflammatory agent in a similar way. Bacterial colonization of the human host is dependent on the modulation of immune responses, such as complement activation and neutrophil chemotaxis. When serotype M1 strains of $S$. pyogenes are cultured in vitro, SIC is expressed in the early exponential phase of growth (Åkesson et al., 1996; Mangold et al., 2004), and it is likely that SIC blocks contact activation during the initial phase of streptococcal colonization. Relatively large amounts of SIC were needed to inhibit kaolin-induced contact activation. Kaolin is an artificial and nonphysiological activator of the contact system with a very large surface area and net charge. It is considered to be one of the most potent activators, and thus high concentrations of protein SIC are required to occupy and neutralize all contact system binding sites of this substance. Indeed, other substances that interfere with kaolin-evoked contact activation have had to be used at high concentrations before an effect could be recorded (Persson et al., 2000; Oehmcke et al., 2009). In vivo, the concentration of SIC that will interfere with contact activation is probably lower. Also, SIC is the dominant streptococcal product in the early growth phase and is expressed at high levels (Åkesson et al., 1996), and it is likely that SIC concentrations are high in vivo, especially close to the bacterial surface. By inhibiting the increased vascular permeability induced by BK, SIC could counteract the recruitment of granulocytes to the site of infection. Plasma leakage into the infectious focus will also result in the binding of contact factors to the bacterial surface, and the subsequent assembly and activation of the contact system will generate antibacterial peptides (Frick et al., 2006). Inactivation of these peptides and the anti-inflammatory effect of SIC should promote bacterial colonization and survival in this early phase of infection.

All serotypes of S. pyogenes secrete a cysteine proteinase, SpeB. This enzyme is a well-established virulence determinant, which solubilizes biologically active fragments of $S$. pyogenes surface proteins (Berge \& Björck, 1995), and also cleaves a wide range of host molecules (Kapur et al., 1993a, b). Previous work has demonstrated that SpeB efficiently cleaves kininogens to release BK (Herwald et al., 1996a), a mechanism that could help to explain the hypovolaemic hypotension and shock seen in severe $S$. pyogenes infections. It has also been shown that kininogens, bound to the surface of $S$. pyogenes via $\mathrm{M}$ protein, are cleaved by SpeB followed by the local release of BK (Ben Nasr et al., 1997). This effect of SpeB contrasts with the inhibition of BK generation by SIC described here, indicating that $S$. pyogenes uses dual mechanisms in its interactions with the contact system. Initially SIC protects the bacteria from the inflammatory and innate responses, whereas later during the infectious process when $S$. pyogenes enters a stationary growth phase and SpeB is being expressed, the enzyme induces plasma leakage that will serve as a source of nutrients and facilitate dissemination of the infection.

As mentioned, there are more than 120 different $\mathrm{M}$ serotypes, and the high prevalence of the M1 serotype 
during the last 30 years has puzzled researchers in the field. Obviously, S. pyogenes strains of this serotype have selective advantages compared with isolates of other serotypes, and interference with contact system activation by SIC could help to explain the evolutionary success of M1 bacteria.

\section{ACKNOWLEDGEMENTS}

This work was supported by grants from the Swedish Research Council (projects 7480.9915 and 13419), the Medical Faculty, Lund University, the Royal Physiographic Society in Lund, the Kock, Lundberg, Torsten, Ragnar Söderberg and Anders Österlund Foundations, and Hansa Medical AB. The authors have no conflicting financial interests.

\section{REFERENCES}

Abrahamson, M. (1994). Cystatins. Methods Enzymol 244, 685-700. Abrahamson, M., Barrett, A. J., Salvesen, G. \& Grubb, A. (1986), Isolation of six cysteine proteinase inhibitors from human urine. Their physicochemical and enzyme kinetic properties and concentrations in biological fluids. J Biol Chem 261, 11282-11289.

Abrahamson, M., Dalboge, H., Olafsson, I., Carlsen, S. \& Grubb, A. (1988). Efficient production of native, biologically active human cystatin C by Escherichia coli. FEBS Lett 236, 14-18.

Åkesson, P., Cooney, J., Kishimoto, F. \& Björck, L. (1990). Protein $\mathrm{H}$ - a novel IgG binding bacterial protein. Mol Immunol 27, 523531.

Åkesson, P., Schmidt, K. H., Cooney, J. \& Björck, L. (1994). M1 protein and protein $\mathrm{H}$ : IgGFc- and albumin-binding streptococcal surface proteins encoded by adjacent genes. Biochem $J$ 300, 877886.

Åkesson, P., Sjöholm, A. G. \& Björck, L. (1996). Protein SIC, a novel extracellular protein of Streptococcus pyogenes interfering with complement function. J Biol Chem 271, 1081-1088.

Auerswald, E. A., Rossler, D., Mentele, R. \& Assfalg-Machleidt, I. (1993). Cloning, expression and characterization of human kininogen domain 3. FEBS Lett 321, 93-97.

Ben Nasr, A., Olsén, A., Sjöbring, U., Müller-Esterl, W. \& Björck, L. (1996). Assembly of human contact phase proteins and release of bradykinin at the surface of curli-expressing Escherichia coli. Mol Microbiol 20, 927-935.

Ben Nasr, A., Herwald, H., Sjöbring, U., Renne, T., Müller-Esterl, W. \& Björck, L. (1997). Absorption of kininogen from human plasma by Streptococcus pyogenes is followed by the release of bradykinin. Biochem J 326, 657-660.

Berge, A. \& Björck, L. (1995). Streptococcal cysteine proteinase releases biologically active fragments of streptococcal surface proteins. J Biol Chem 270, 9862-9867.

Bhoola, K. D., Figueroa, C. D. \& Worthy, K. (1992). Bioregulation of kinins: kallikreins, kininogens, and kininases. Pharmacol Rev 44, 1-80.

Binks, M. J., Fernie-King, B. A., Seilly, D. J., Lachmann, P. J. \& Sriprakash, K. S. (2005). Attribution of the various inhibitory actions of the streptococcal inhibitor of complement (SIC) to regions within the molecule. J Biol Chem 280, 20120-20125.

Colman, R. W. \& Schmaier, A. H. (1997). Contact system: a vascular biology modulator with anticoagulant, profibrinolytic, antiadhesive, and proinflammatory attributes. Blood 90, 3819-3843.

Colman, R. W., Pixley, R. A., Najamunnisa, S., Yan, W., Wang, J., Mazar, A. \& McCrae, K. R. (1997). Binding of high molecular weight kininogen to human endothelial cells is mediated via a site within domains 2 and 3 of the urokinase receptor. J Clin Invest 100, 14811487.

Curtis, N. (1996). Invasive group A streptococcal infection. Curr Opin Infect Dis 9, 191-202.

de Château, M. \& Björck, L. (1994). Protein PAB, a mosaic albuminbinding bacterial protein representing the first contemporary example of module shuffling. J Biol Chem 269, 12147-12151.

DeLa Cadena, R. A. \& Colman, R. W. (1992). The sequence HGLGHGHEQQHGLGHGH in the light chain of high molecular weight kininogen serves as a primary structural feature for zincdependent binding to an anionic surface. Protein Sci 1, 151-160.

Egesten, A., Eliasson, M., Johansson, H. M., Olin, A. I., Mörgelin, M., Mueller, A., Pease, J. E., Frick, I. M. \& Björck, L. (2007). The CXC chemokine MIG/CXCL9 is important in innate immunity against Streptococcus pyogenes. J Infect Dis 195, 684-693.

Facklam, R. F., Martin, D. R., Lovgren, M., Johnson, D. R., Efstratiou, A., Thompson, T. A., Gowan, S., Kriz, P., Tyrrell, G. J. \& other authors (2002). Extension of the Lancefield classification for group A streptococci by addition of 22 new M protein gene sequence types from clinical isolates: emm103 to emm124. Clin Infect Dis 34, 28-38.

Fernie-King, B. A., Seilly, D. J., Davies, A. \& Lachmann, P. J. (2002). Streptococcal inhibitor of complement inhibits two additional components of the mucosal innate immune system: secretory leukocyte proteinase inhibitor and lysozyme. Infect Immun 70, 4908-4916.

Fischetti, V. A. (1989). Streptococcal M protein: molecular design and biological behavior. Clin Microbiol Rev 2, 285-314.

Frick, I. M., Åkesson, P., Rasmussen, M., Schmidtchen, A. \& Björck, L. (2003). SIC, a secreted protein of Streptococcus pyogenes that inactivates antibacterial peptides. J Biol Chem 278, 16561-16566.

Frick, I. M., Åkesson, P., Herwald, H., Mörgelin, M., Malmsten, M., Nägler, D. K. \& Björck, L. (2006). The contact system - a novel branch of innate immunity generating antibacterial peptides. EMBO J 25, 5569-5578.

Grubb, A. (1992). Diagnostic value of analysis of cystatin C and protein HC in biological fluids. Clin Nephrol 38 (Suppl. 1), S20S27.

Hartas, J. \& Sriprakash, K. S. (1999). Streptococcus pyogenes strains containing emm12 and emm55 possess a novel gene coding for distantly related SIC protein. Microb Pathog 26, 25-33.

Hasan, A. A., Cines, D. B., Herwald, H., Schmaier, A. H. \& MüllerEsterl, W. (1995). Mapping the cell binding site on high molecular weight kininogen domain 5. J Biol Chem 270, 19256-19261.

Hasan, A. A., Zisman, T. \& Schmaier, A. H. (1998). Identification of cytokeratin 1 as a binding protein and presentation receptor for kininogens on endothelial cells. Proc Natl Acad Sci U S A 95, 36153620 .

Herwald, H., Hasan, A. A., Godovac-Zimmermann, J., Schmaier, A. H. \& Müller-Esterl, W. (1995). Identification of an endothelial cell binding site on kininogen domain D3. J Biol Chem 270, 14634-14642.

Herwald, H., Collin, M., Müller-Esterl, W. \& Björck, L. (1996a). Streptococcal cysteine proteinase releases kinins: a virulence mechanism. J Exp Med 184, 665-673.

Herwald, H., Dedio, J., Kellner, R., Loos, M. \& Müller-Esterl, W. (1996b). Isolation and characterization of the kininogen-binding protein $\mathrm{p} 33$ from endothelial cells. Identity with the gC1q receptor. J Biol Chem 271, 13040-13047.

Herwald, H., Mörgelin, M., Olsén, A., Rhen, M., Dahlbäck, B., MüllerEsterl, W. \& Björck, L. (1998). Activation of the contact-phase system 
on bacterial surfaces - a clue to serious complications in infectious diseases. Nat Med 4, 298-302.

Herwald, H., Mörgelin, M., Svensson, H. G. \& Sjöbring, U. (2001). Zinc-dependent conformational changes in domain D5 of high molecular mass kininogen modulate contact activation. Eur J Biochem 268, 396-404.

Hoe, N. P., Nakashima, K., Lukomski, S., Grigsby, D., Liu, M., Kordari, P., Dou, S. J., Pan, X., Vuopio-Varkila, J. \& other authors (1999). Rapid selection of complement-inhibiting protein variants in group A Streptococcus epidemic waves. Nat Med 5, 924-929.

Kapur, V., Majesky, M. W., Li, L. L., Black, R. A. \& Musser, J. M. (1993a). Cleavage of interleukin 1 beta (IL-1 beta) precursor to produce active IL-1 beta by a conserved extracellular cysteine protease from Streptococcus pyogenes. Proc Natl Acad Sci U S A 90, 7676-7680.

Kapur, V., Topouzis, S., Majesky, M. W., Li, L. L., Hamrick, M. R., Hamill, R. J., Patti, J. M. \& Musser, J. M. (1993b). A conserved Streptococcus pyogenes extracellular cysteine protease cleaves human fibronectin and degrades vitronectin. Microb Pathog 15, 327-346.

Koide, T. \& Odani, S. (1987). Histidine-rich glycoprotein is evolutionarily related to the cystatin superfamily. Presence of two cystatin domains in the N-terminal region. FEBS Lett 216, 17-21.

Lukomski, S., Hoe, N. P., Abdi, I., Rurangirwa, J., Kordari, P., Liu, M., Dou, S. J., Adams, G. G. \& Musser, J. M. (2000). Nonpolar inactivation of the hypervariable streptococcal inhibitor of complement gene (sic) in serotype M1 Streptococcus pyogenes significantly decreases mouse mucosal colonization. Infect Immun 68, 535-542.

Mangold, M., Siller, M., Roppenser, B., Vlaminckx, B. J., Penfound, T. A., Klein, R., Novak, R., Novick, R. P. \& Charpentier, E. (2004). Synthesis of group A streptococcal virulence factors is controlled by a regulatory RNA molecule. Mol Microbiol 53, 1515-1527.

Martin, D. R. \& Single, L. A. (1993). Molecular epidemiology of group A streptococcus M type 1 infections. J Infect Dis 167, 1112-1117.

Mason, J. W., Kleeberg, U., Dolan, P. \& Colman, R. W. (1970). Plasma kallikrein and Hageman factor in Gram-negative bacteremia. Ann Intern Med 73, 545-551.

Mattsson, E., Herwald, H., Cramer, H., Persson, K., Sjöbring, U. \& Björck, L. (2001). Staphylococcus aureus induces release of bradykinin in human plasma. Infect Immun 69, 3877-3882.

Müller-Esterl, W., Johnson, D. A., Salvesen, G. \& Barrett, A. J. (1988). Human kininogens. Methods Enzymol 163, 240-256.

Musser, J. M. \& Krause, R. M. (1998). The revival of group A streptococcal diseases with a commentary on staphylococcal toxic shock syndrome. In Emerging Infections, pp. 185-218. Edited by R. M. Krause \& A. Fauci. San Diego: Academic Press.

Musser, J. M., Kapur, V., Kanjilal, S., Shah, U., Musher, D. M., Barg, N. L., Johnston, K. H., Schlievert, P. M., Henrichsen, J. \& other authors (1993). Geographic and temporal distribution and molecular characterization of two highly pathogenic clones of Streptococcus pyogenes expressing allelic variants of pyrogenic exotoxin A (Scarlet fever toxin). J Infect Dis 167, 337-346.

Oehmcke, S., Shannon, O., von Köckritz-Blickwede, M., Mörgelin, M., Linder, A., Olin, A. I., Björck, L. \& Herwald, H. (2009). Treatment of invasive streptococcal infection with a peptide derived from human high-molecular weight kininogen. Blood 114, 444-451.

Persson, K., Mörgelin, M., Lindbom, L., Alm, P., Björck, L. \& Herwald, H. (2000). Severe lung lesions caused by Salmonella are prevented by inhibition of the contact system. J Exp Med 192, 1415-1424.

Pixley, R. A., Zellis, S., Bankes, P., DeLa Cadena, R. A., Page, J. D., Scott, C. F., Kappelmayer, J., Wyshock, E. G., Kelly, J. J. \& Colman, R. W. (1995). Prognostic value of assessing contact system activation and factor $\mathrm{V}$ in systemic inflammatory response syndrome. Crit Care Med 23, 41-51.

Schmaier, A. H. \& Colman, R. W. (1989). Platelet high-molecularweight kininogen. Methods Enzymol 169, 276-296.

Stockbauer, K. E., Grigsby, D., Pan, X., Fu, Y. X., Mejia, L. M., Cravioto, A. \& Musser, J. M. (1998). Hypervariability generated by natural selection in an extracellular complement-inhibiting protein of serotype M1 strains of group A Streptococcus. Proc Natl Acad Sci U S A 95, 3128-3133.

Tait, J. F. \& Fujikawa, K. (1987). Primary structure requirements for the binding of human high molecular weight kininogen to plasma prekallikrein and factor XI. J Biol Chem 262, 11651-11656.

van Deuren, M., Brandtzaeg, P. \& van der Meer, J. W. (2000). Update on meningococcal disease with emphasis on pathogenesis and clinical management. Clin Microbiol Rev 13, 144-166.

Wachtfogel, Y. T., DeLa Cadena, R. A., Kunapuli, S. P., Rick, L., Miller, M., Schultze, R. L., Altieri, D. C., Edgington, T. S. \& Colman, R. W. (1994). High molecular weight kininogen binds to Mac-1 on neutrophils by its heavy chain (domain 3) and its light chain (domain 5). J Biol Chem 269, 19307-19312.

Wuillemin, W. A., Fijnvandraat, K., Derkx, B. H., Peters, M., Vreede, W., ten Cate, H. \& Hack, C. E. (1995). Activation of the intrinsic pathway of coagulation in children with meningococcal septic shock. Thromb Haemost 74, 1436-1441.

Edited by: T. J. Mitchell 